\begin{tabular}{|c|c|}
\hline $\begin{array}{l}\text { RESEARCH } \\
\text { ARTICLE }\end{array}$ & $\begin{array}{l}\text { ADVANCE RESEARCH JOURNAL OF SOCIAL SCIENCE } \\
\text { Volume } 10 \mid \text { Issue } 1 \mid \text { June, 2019 | } 1-5 \text { ISSN-0976-5611 }\end{array}$ \\
\hline $0=$ & DOI: 10.15740/HAS/ARJSS/10.1/1-5 \\
\hline
\end{tabular}

\title{
A comparative study on marital adjustment among single and dual earner retired couples
}

Priyanka Rathore* and Gaytri Tiwari Department of Human Development and Family Studies, College of Community and Applied Sciences, Maharana Pratap University of Agriculture and Technology, Udaipur (Rajasthan) India

(Email : pinky.1995.pr@gmail.com, Tiwarigaytri@gmail.com)

\section{ARTICLE INFO :}

$\begin{array}{lll}\text { Received } & : & 19.04 .2019 \\ \text { Revised } & : & 01.05 .2019 \\ \text { Accepted } & : & 11.05 .2019\end{array}$

KEY WORDS :

Marital adjustment, Single earner, Dual earner, Retired couples

HOW TO CITE THIS ARTICLE :

Rathore, Priyanka and Tiwari, Gaytri (2019). A comparative study on marital adjustment among single and dual earner retired couples. Adv. Res. J. Soc. Sci., 10 (1) : 1-5, DOI: 10.15740/HAS/ARJSS/ 10.1/1-5. Copyright@2019 : Hind Agri Horticultural Society

*Author for correspondence

\begin{abstract}
Marriage is a beautiful relationship in which two people live together and faces so many hurdles together, live so many precious memories together. In marriage two people need to fully understand each other and give their best to make their relationship last forever. Therefore, present study was conducted with an objective to compare the marital adjustment of single and dual earner retired couples. The total sample consisted of 60 retired couples that are 30 single earners and 30 dual earners couples; the age range was $60+$ years belonging to the empty nest stage of family life cycle. A self prepared background information proforma was used to collect the information regarding the personal and background aspects of the subjects. Marital adjustment scale developed by Tiwari et al. (2017) with some modifications was administered on the subjects to compare the marital adjustment of single and dual earner retired couples. The data obtained were analyzed in the light of objective by calculating frequency, percentage, mean scores and t- values. Major findings of the study indicated that majority of the single and dual earner retired couples had average level of marital adjustment, respectively. The subjects had a significant difference in overall and dimensions i.e. physical and economical. It can be conclude that proper psychosocial system and mutual understanding of the couples plays prime role in the well being during empty-nest stage.
\end{abstract}

